\title{
Madrasah Management in Organizing Learning Process During Pandemic Covid 19
}

\author{
Elianah $^{1 *)}$, Happy Fitria ${ }^{2}$, Syaiful Eddy ${ }^{2}$ \\ ${ }^{1}$ MTs Ahliyah 1 Palembang, South Sumatra, Indonesia \\ ${ }^{2}$ Universitas PGRI Palembang, Indonesia \\ *Corresponding author. Email: elianah669@gmail.com
}

\begin{abstract}
The purpose of this research is to know and describe the management of Madrasah Tsanawiyah Ahliyah 1 Palembang in carrying out the learning process during Covid 19; to know and describe the obstacles faced by Madrasahs in implementing learning management during Covid 19 and to know and describe the efforts to overcome obstacles faced in carrying out the learning process during Covid 19 at MTs Ahliyah 1 Palembang. This research is a qualitative research. The methods used to collect data are interviews, observation and documentation. Data analysis techniques in this study use data reduction, Data Display and Drawing / Verifying Conclusion. The results of the study stated that MTs Ahliyah 1 continued to carry out the teaching and learning process well despite the pandemic. The implementation of learning uses learning media with the WhatsApp application where teachers and subjects remain the same as usual. The obstacles faced by students and teachers are the lack of student activity in participating in learning, the difficulty of students in understanding the material due to the long distance from the teacher, some students do not have quotas and learning aids such as cell phones, making it difficult for students to learn online. Madrasah overcome student learning problems by working with parents to ask for supervision assistance, giving assignments directly to students and gathering to school. Implementation management at MTS Ahliyah 1 Palembang as long as Covid can be implemented well as planned by Madrasah.
\end{abstract}

Keywords: Management, Madrasah, Covid 19

\section{INTRODUCTION}

A quality madrasah is a madrasah that has good management because with good management a madrasah can plan, implement and evaluate the strengths and weaknesses of the madrasah itself so that it can go according to what has been planned. As the leader of the madrasah, the person who is fully responsible for advancing the madrasah is a Madrasah principal who has the ability in the field of management.

According to [1], "A principal who has good managerial skills must be able to organize his school activities based on current conditions leading to better conditions. Therefore, it is highly demanded that the principal's ability to design school development plans, distribute activities, motivate and foster teachers and school staff in carrying out their duties every day, and measure and assess the performance of their staff.

Management comes from the word "to manage" which means to organize, manage or manage While madrasah comes from Arabic which means a place or vehicle to experience the learning process. In Indonesian madrasah is called a school which means a building or institution for learning and teaching [2]. From the above opinion it can be concluded that madrasah management is a way of managing, managing, or managing the teaching and learning process which is carried out in one place called a school or madrasah.

Madrasah / school management is often known as education management. Madrasah / school management is part of education management. Where education management implies as a systematic, systemic and comprehensive cooperation process in order to realize national education goals that are broader in the scope of its management, while madrasah / school management is management made in the school / madrasah itself.

According to [3], "Madrasah management has seven components that must be well managed by a madrasah or school, namely in the areas of curriculum management and teaching programs, education personnel, students, finance, educational facilities and infrastructure, management of school and community 
relations. and management of special services for educational institutions. The number of components in madrasah management requires a considerable amount of time to be studied so that in this study the researchers only looked at the madrasah management process in the field of curriculum management and teaching programs.

According to [4], "Curriculum management is activities that are planned and implemented to make it easier for teachers and students to carry out the learning process". Activities included in curriculum management include the division of teacher duties, preparation of lesson schedules, division of study groups, making teacher and student attendance, establishing extracurricular activities, making a list of grades, determining exam time and so on. All of these activities are aimed at making it easy for teachers and students to carry out learning as a core school activity.

Furthermore, according to [5], "curriculum management is the whole process of joint efforts to facilitate the achievement of teaching goals with an emphasis on improving the quality of teaching and learning interactions." From some of the opinions above, it can be concluded that curriculum management is the application of types of activities and management functions to facilitate the achievement of learning objectives with an emphasis on the efforts made by management executives. From some of the opinions above, it can be concluded that curriculum management is the application of types of activities and management functions to facilitate the achievement of learning objectives with an emphasis on the efforts made by management executives.

According to [6], "suggests the curriculum management cycle which consists of four stages, namely the planning stage, the development stage, the implementation or implementation stage and the assessment stage". The four stages in curriculum management have each stage again. Because of the breadth of the curriculum management cycle, the research conducted research on madrasah management within the scope of the learning process.

The implementation or implementation phase includes the following steps: (1) Preparing learning plans and programs (syllabus, lesson plans / lesson plans); (2) description of the material; (3) Determination of learning strategies and methods; (4) Providing learning resources, tools and facilities; (5) determining the methods and tools for assessing the learning process and outcomes; and (6) learning environment setting.

The implementation of learning or learning systems that have existed in Indonesia since ancient times until now has occurred in the learning process directly meeting teachers and students who are shaded by an institution called a school or madrasah although currently there are also several educational institutions that use learning media from a distance far but the majority of education in Indonesia uses a face-to-face system that has set subject hours, teachers, and what activities are carried out by students and teachers by the stakeholders of each madrasah but the learning system suddenly changes drastically students must learn at home due to a pandemic outbreak known as Covid-19.

Corona virus disease 2019 (corona virus disease / COVID-19) is a new name given by the World Health Organization (WHO) for those with the 2019 corona novel virus infection which was first reported from the city of Wuhan, China at the end of 2019. The spread occurred rapidly. The process of transmitting this virus has made various sectors change, one of which is the education sector.

Based on the Circular of the Head of the Palembang Education Office on March 16, 2020, it was stated that all public and private TK / PAUD / SD / SMP education units under the authority of the city of Palembang temporarily divert learning activities from schools / institutions to homes on March 17 to 28 2020. Since the letter was circulated, students studied from home suddenly since March and until now students are still studying at home according to a circular regarding the extension of the learning process with letter number 421/3 / SE/Disdik/ 2020 which contains an extension of time study until November 30, 2020. This sudden change inevitably forces schools or madrasas to make changes in curriculum management, programs that have been planned to change, which usually occur face-toface, now students learn remotely, known as online learning students. or online.

A sudden change of course has its own challenges both from teachers, students and parents who are the main supervisors in supervising students studying at home. The Covid-19 pandemic has forced millions of students to study at home and meanwhile many of the educators suddenly become "stuttering teaching" because they have to change the way of teaching drastically from face-to-face to online suddenly.

The learning system is implemented through a personal computer (PC) or laptop connected to an internet network connection. Teachers can learn together at the same time using groups on social media such as WhatsApp (WA), telegram, Instagram, zoom applications or other media as learning media. This online or online learning media also requires or forces parents to facilitate students with cell phones, laptops and of course Internet quotas. What is not cheap for parents in economic conditions that are in the middle to lower line and in one house there are many children who are taking education or studying at home.

There are many challenges in facing Covid. Researchers conducted research on madrasah 
management in carrying out the teaching and learning process during Covid 19 at MTs Ahliyah 1 Palembang.

\section{METHODS}

The research method in this study is a qualitative research method. The qualitative research approach is a process of research and understanding which is based on a method that investigates a social phenomenon and human problems. In this study, researchers made a complex picture, examined words, detailed reports from the views of respondents and conducted studies in natural situations [7].

According to [8] qualitative methods are carried out with several considerations, first adjusting qualitative methods is easier when dealing with multiple realities; second, this method provides a direct relationship between the researcher and the respondent; third, this method is more sensitive and can adapt to a lot of sharpening the joint influence and to the value patterns faced, while according to [9] qualitative research is descriptive, namely an analysis that describes the state or status of a phenomenon with words or sentences, then separated according to categories to get the conclusion that qualitative research is research that directly observes and describes the analysis of the situation in words or sentences reported in detail by the researcher. During the study, the researcher is the main instrument. In an effort to collect data, the researcher carried out the interview, observation and documentation process to find out the process of implementing online learning during Covid, as well as the obstacles and solutions made by the madrasah so that the researcher could describe it clearly.

The technique in analysing research data uses the Miles and Huberman model in [10] which includes the following stages of data analysis; Data Reduction, Display and Drawing / Verifying Conclusion.

\section{RESULTS AND DISCUSSION}

\section{a. Madrasah management in carrying out the teaching and learning process during Covid 19 at MTs Ahliyah 1 Palembang.}

Based on the results of interviews with the head of Madrasah and the Deputy Curriculum of MTs Ahliyah 1 , there were several things that were carried out in preparing the learning process which was carried out both at the learning planning stage, the implementation stage and the evaluation stage. The following are the results of the interview:

\section{At the Planning Stage:}

a. Madrasah hold a new school year meeting where in the meeting discussing the workload of the teacher or making a teaching work division decision.

b. The head of the Madrasah appoints a homeroom teacher for each class from grade $7 \mathrm{~A}$ to grade $9 \mathrm{~B}$

c. The head of the Madrasah invites the parents of the guardians of the students for cooperation between the school and the guardians of the students who are at home

d. The curriculum representative, assisted by the homeroom teacher, creates a study group. By managing students who have cellphones and student cellphone numbers as well as students who do not have cellphones. In this case MTs Ahliyah 1 only uses application learning media via Whatsapp. Because MTs Ahliyah consists of 6 classes, namely from class 7 two classes (7A and 7B), Class 8 (8A and 8B) and classes 9A and 9B. Every teacher who teaches is in the group.

e. The teacher makes learning tools according to the covid 19 study guide where the lesson plan is made only as short as about 1 sheet.

Judging from the statement by Majid in the journal [11] reveals that planning is a process of compiling subject matter, using teaching media, using teaching approaches and methods, and assessing in a time allocation that will be carried out in it can be concluded that MTs Ahliyah 1 has carried out the learning planning process well.

\section{At the Implementation Stage}

Based on the results of the interview from the deputy head of the madrasah: at the learning implementation stage:

a. The Curriculum Representative regulates student learning schedules during covid 19 Student learning schedules are shortened to study hours which are usually 07.10 to 13.30 shortened to 08.00 to 12.00 hours

b. Subjects in one day are arranged into 4 subjects where each teacher is given only 1 hour to provide learning material.

c. The teacher makes learning reports once a month and evaluates learning on active and inactive students.

d. The teacher teaches according to the lesson schedule with online learning media "WhatsApp" with a pre-designed lesson plan guide. Where the learning activities consist of Initial, Core and Closing activities. 


\section{Evaluation Phase}

At the evaluation stage, there are two evaluations carried out by the head of Madrasah and madrasah, namely the evaluation of learning for teachers and evaluation of the learning process in students which are detailed as follows:

\section{a. Learning Evaluation by the principal of madrasah (Supervision) for teachers}

The head of Madrasah, who is also assisted by the Deputy Head of Madasah for the curriculum section, supervises the learning of the teachers. During the Covid 19 period, the supervision of the Head of Madrasah in supervising the way teachers taught was more comfortable and could be done at any time because online learning involved all those who played a role in the learning process into one WhatsApp group application. Administratively, the representative sees the teacher's report once a month in the learning process. If there are things that need to be followed up, the madrasah principal and the teacher discuss in different groups directly so that they get a quick solution.

\section{b. Evaluation of the learning process by the teacher for students}

The evaluation for students that is regulated by the madrasah is a schedule for midterm and final semester exams that are arranged in the Education calendar by the Madrasah Curriculum Representative. The test management carried out by MTs Ahliyah 1 Palembang uses the google form application where it is made and students can answer online as well as at home online, the results of student exams are reported to parents. covid 19 rules keep your distance and wear a mask. The madrasah organizes student examinations in 2 sessions consisting of the first session in the morning at 7.00 to 09:30 and the second session at 10 to 12 .

\section{b. The Obstacles in implementing learning during Covid 19 at MTs Ahliyah 1 Palembang.}

Based on the results of interviews with the principal of madrasah and curriculum representatives and two MTs Ahliyah 1 Palembang teachers. There are obstacles faced by students and teachers including:

a) The lack of active students who are present when studying at the teacher's house at school.

b) If usually $97 \%$ can attend face-to-face online, only $75 \%$ of the student's activity level is learning.

c) There are some students who do not have cell phones and learning quotas are used as excuses by students to study online d) Shared hp facilities

e) There is no strong will for students to study online, this can be seen when the submission of assignments is not optimal.

f) Lack of parental understanding of technology causes some parents to be unable to control their children studying at home. So that cell phones are often used to play online games

g) The decreased level of student understanding of a subject matter

\section{c. Madrasah efforts in dealing with online learning difficulties}

Several attempts have been made from madrasas to overcome problems that arise during online learning, namely:

1. Madrasah collaborate with parents to supervise students directly.

2. Students who do not have a cell phone, come to school to ask for material from the teacher then take the assignment home or there are also get direct guidance at school while maintaining $3 \mathrm{M}$ wearing a mask, keep your distance and wash your hands.

3. Homeroom teacher provides the best service for students to continue learning. If not present in the learning process, students who are not actively called or sought so that these students can actively study again.

\section{CONCLUSION}

The teaching and learning process at MTS Ahliyah 1 Palembang during Covid 19 has been carried out well, it can be seen that Madrasah Ahliyah 1 have carried out good planning in carrying out the learning process where the madrasah has arranged the Academic Calendar, has arranged the teaching load of teachers, the teachers have made preparations learning tools before implementing learning and each teacher evaluating learning. Despite the distance learning process between teachers and students, good communication from madrasah to parents, teaching and learning activities can still be carried out even with many shortcomings and obstacles. This should be reconsidered by madrasah to improve the online learning system, maybe in the future it can make student learning spaces better online so that they don't only use cell phones but have their own ELearning for students to access the material. 


\section{REFERENCES}

[1] Marce, S., Ahmad., S \& Eddy, S. (2020) Leadership managemen principal As Administrator in increasing teacher competence. Dawuh Journal.1(2) 76-80

[2] Arif, M. (2013). Madrasah Management in an Effort to Improve the Quality of Islamic Education Episteme.8(2):418.

[3] Mulyasa, E. (2002) School Based Management. Bandung: Remaja Rosdakarya.

[4] Lubis, A. Y. (2015) Implementation of Curriculum Management at SMA Negeri 1 Buengcala Aceh Besar District. Jurnal Administari Pendidikan Pascasarjana Universitas Syiah Kuala. 3(1): 15-23.

[5] Haryati, Mimin (2007). Assessment Models and Techniques at the education unit level. Jakarta: Gaung Persada Press.

[6] Rusman (2012) Curriculum Management.Jakarta: Rajawali Pers.

[7] Iskandar (2009). Qualitative Research Methodology. Jakarta: Gaung Persada.

[8] Lexy J, Moleong. (2017) Qualitative Research Methodology. Bandung: Remaja Rosdakarya.

[9] Arikunto, Suharsimi. 2013. Research Procedure A Practice Approach. Jakarta: Rineka Cipta.

[10] Rijali, Ahmad (2018). Qualitative Data Analysis. Jurnal Alhadharah. 17(33): 83-90.
[11] Saparahayuningsih, A., \& Fitri, E. A. (2017). Planning for Learning Curriculum 2013 for Early Childhood Education (Quantitative Descriptive Research in PAUD IT Auladuna Bengkulu City). Jurnal Potensia.PG-PAUD FKIP UNIB. 2(1):3.

[12] Gunawan, I. (2017, September). Indonesian Curriculum 2013: Instructional Management, Obstacles Faced By Teachers In Implementation And The Way Forward. In 3rd International Conference On Education And Training (ICET 2017). Atlantis Press.

[13] Andriningrum, H., \& Gunawan, I. (2018, December). Cultivatation of Healthy Life for Students in School: A Literature Review. In International Conference on Education and Technology (ICET 2018). Atlantis Press.

[14] Argadinata, H., \& Gunawan, I. (2019, December). The Leadership of Pancasila in Education: Foundation for Strengthening Student Characters in the Industrial Revolution Era 4.0. In the 4th International Conference on Education and Management (COEMA 2019). Atlantis Press.

[15] Pambudi, B. A., \& Gunawan, I. (2019, December). Instructional Leadership as an Effort to Increase Teacher Professionalism in the Industrial Revolution Era 4.0. In the 4th International Conference on Education and Management (COEMA 2019). Atlantis Press. 